\title{
Tolling the Deadline for Appealing in Absentia Deportation Orders Due to Ineffective Assistance of Counsel
}

\author{
Damon W. Taaffe $\dagger$
}

Ruben Lopez, a native and citizen of Mexico, entered the United States illegally and retained an attorney to assist him in obtaining a work permit. He paid $\$ 350$ for the representation. Noel, his attorney, told Lopez to bring any Immigration and Naturalization Service ("INS") correspondence to him immediately so that he might take care of it.

Instead of seeking a work permit as Lopez requested, Noel filed an application for political asylum. When Lopez received notice of his asylum hearing, Noel told him that he need not appear at the hearing, and charged him another $\$ 100$. Lopez heeded his attorney's advice and did not attend the hearing, but neither did Noel, and Lopez received notice that his case had been referred to an Immigration Judge ("IJ") for a deportation hearing. Again, Noel advised Lopez that he would appear on his behalf, and Lopez paid him an additional $\$ 400$. Again, neither Lopez nor Noel appeared at the deportation hearing, and the $\mathrm{IJ}$ issued a deportation order in absentia.

Upon receiving notice of the IJ's order, Lopez became suspicious and confronted Noel. It turned out that Noel was actually a notary public, not an attorney. Lopez immediately retained new counsel and filed an appeal due to the "exceptional circumstance[ ]" of ineffective assistance of counsel, but it was too late - the Immigration and $\mathrm{Na}$ tionality Act ("INA") $§ 1229$ a's 180-day deadline for appealing deportation orders ${ }^{3}$ had lapsed.

In such cases, aliens frequently ask the court to "equitably toll" the filing deadline. Equitable tolling "ensures fundamental fairness" by allowing courts to extend statutory deadlines when justice so requires. 'Today, the outcome of such a tolling request would likely depend on what court hears the appeal. The anti-tolling courts, epitomized by the Eleventh Circuit, view the filing deadline as a jurisdic-

$\dagger$ B.A. 1999, Swarthmore College; J.D. Candidate 2002, The University of Chicago.

1 See Lopez $v$ INS, 184 F3d 1097, 1098 (9th Cir 1999). This scenario borrows the facts of that case.

28 USC $\$ 1229 a(b)(5)(C)(i)$ (1994 \& Supp 1999).

3 Id.

4 Morris v Government Development Bank of Puerto Rico, 27 F3d 746, 750 (1st Cir 1994). 
tional limit rather than a statute of limitations. ${ }^{5}$ Since jurisdictional limits prevent a court from hearing a case on its merits, adherents to this view hold that courts cannot toll the filing deadline regardless of any consequent injustice.

The Ninth Circuit stands in sharp contrast to the Eleventh Circuit, holding that Section 1229a is a tollable statute of limitations, and that alleged fraud, an extreme form of ineffective assistance, can be sufficient to justify tolling.' It explicitly rejects the Eleventh Circuit's finding of a jurisdictional limit within the INA. The First Circuit has also signaled its receptiveness to tolling, so long as a petitioner is duly diligent.

Analyzing equitable tolling's propriety in the deportation context thus entails two distinct inquiries. First, is the filing deadline properly viewed as a jurisdictional limit per the Eleventh Circuit,' or a statute of limitations per the Ninth Circuit? ${ }^{10}$ Second, if the Ninth Circuit is correct and courts possess the power to toll equitably, should they toll for appeals that are tardy due to alleged ineffective assistance of counsel?

This Comment proposes that in situations where an alien or his attorney receives notice of a pending deportation hearing, courts should draw a misfeasance-nonfeasance distinction and equitably toll the deadline only when an attorney's material misrepresentations proximately cause an alien to miss his hearing. This approach balances two somewhat competing ideals: that a client should be able to rely on his attorney's reasonable representations without fear of penalty, and that a client should actively pursue his own case.

The Comment is divided into three Parts. Part I discusses the statutory provisions relevant to the analysis. Part II argues that the INA's 180-day appeal deadline is properly viewed as a tollable statute of limitations rather than a jurisdictional limit. The analysis proceeds by examining the statute's text, legislative history, and purpose, and it concludes that there is no indication that Congress intended to curb courts' equitable powers when hearing deportation appeals. Finally, Part III assumes that courts possess the power to toll the 180-day filing deadline and argues that they should apply equitable tolling principles when an alien's attorney induces him not to attend a deporta-

5 See, for example, Anin v Reno, 188 F3d 1273, 1278 (11th Cir 1999) (holding that the INS's 180-day filing deadline provision is "jurisdictional and mandatory"), citing Kamara $v$ INS, 149 F3d 904, 906 (8th Cir 1998).

6 See Anin, 188 F3d at 1278.

7 Lopez, 184 F3d at 1100 (holding that fraud by a notary public posing as an attorney is sufficient to toll the deadline).

8 Jobe v INS, 238 F3d 96, 99 (1st Cir 2001).

9 See Anin, 188 F3d at 1273.

10 See Lopez, 184 F3d at 1100. 
tion hearing and he consequently misses the appeal deadline. In summary, the weight of the evidence suggests that courts can toll the filing deadline, and equity mandates that they do so when an alien alleges that ineffective assistance proximately caused him to miss his appeals deadline.

\section{EQUITABLE TOLLING AND THE IMMIGRATION AND NATIONALITY ACT'S FILING DEADLINES}

Equitable tolling is a judicially created doctrine that allows courts to extend statutory deadlines when justice so requires. Among the three courts of appeals that have addressed the question of when courts should toll Section 1229a's filing deadline, three conclusions emerge. The Eleventh Circuit holds that the deadline is jurisdictional, and courts therefore cannot toll it. The First Circuit suggests that the deadline may be tollable if a petitioner is suitably diligent. The Ninth Circuit goes the furthest, holding that the deadline is tollable and that alleged fraud is sufficient to merit tolling.

\section{A. Statutes of Limitations and Equitable Tolling}

Statutes of limitations are inherently harsh because they "cut off a person's rights without regard to the merits of the claim." "They are also somewhat arbitrary because there is usually no particularly compelling reason to have an appeals period of any given length. ${ }^{12}$ In the INA's case, for example, it is difficult to explain why a 180 -day deadline is superior to one of 170 or 190 days.

Nonetheless, statutes of limitations are an invaluable part of the judicial system. They help to ensure that the finder of fact will not be crippled by the loss of key evidence, ${ }^{13}$ and in so doing, they "maintain the integrity of a statute." Ultimately, however, the Supreme Court

11 Richard Parker and Ugo Colella, Revisiting Equitable Tolling and the Federal Tort Claims Act: The Impact of Brockamp and Beggerly, 29 Seton Hall L Rev 885, 886 (1999).

12 See United States v Locke, 471 US 84, 94 (1985) (noting "the inherent arbitrariness of filing deadlines").

13 Lyman Johnson argues:

[S]tatutes of limitation are vital to the welfare of society and are favored in the law. They are found and approved in all systems of enlightened jurisprudence .... An important public policy lies at their foundation. Among other things, statutes of limitation make the discovery and fact-finding tasks associated with litigation more reliable because courts are freed from having to deal with cases in which the search for truth may be seriously impaired by the loss of evidence, whether by death or disappearance of witnesses, fading memories, disappearance of documents, or otherwise.

14 Salois v Dime Savings Bank of New York, 128 F3d 20, 25 (1st Cir 1997) (explaining both that equitable tolling is applied to prevent unjust results and that courts have taken a narrow view of exceptions to the limitations period), quoting King $v$ California, 784 F2d 910, 915 (9th Cir 
has emphasized that statutes of limitations "are primarily designed to assure fairness to defendants," free of stale claims . . . comes to prevail over the right to prosecute them."

Despite the benefits that come with laying a claim permanently to rest, Congress has recognized that, in certain instances, courts should use their equitable powers to prevent cases of obvious injustice that might arise from mechanically applying a statute of limitations. The equitable tolling doctrine recognizes that due to the inherent imprecision of statutory phrasing, in certain cases the "rigid application" of the limitation period would be unfair and contrary to legislative intent. ${ }^{17}$ In such cases, the doctrine allows courts to "ensure fundamental fairness" by extending statutory time limits when justice so requires. ${ }^{18}$

Equitable tolling finds its roots in Bailey $v$ Glover, ${ }^{19}$ a Supreme Court case from 1875 dealing with a limitation period prescribed in the 1867 Bankruptcy Act. In that case, the Court noted that a person who concealed his fraud until the statute of limitations had run could effectively insulate himself from liability, and therefore it extended the Bankruptcy Act deadline to prevent such injustice. ${ }^{20}$

More recently, in Holmberg $v$ Armbrecht, ${ }^{21}$ the Supreme Court universalized the doctrine, holding that it should be "read into every federal statute of limitation." 22 As Judge Posner explains, in the modern day, equitable tolling is often invoked when a prospective litigant "simply ... cannot with due diligence obtain information essential to bringing a suit.," courts should extend such equitable relief "only sparingly,", but courts have found the doctrine applicable in myriad settings, including

1986).

15 Burnett v New York Central Railroad Co, 380 US 424, 428 (1965).

16 Order of Railroad Telegraphers $v$ Railway Express Agency, Inc, 321 US 342, 349 (1944).

17 Shendock v Director, Office of Worker's Compensation Programs, 893 F2d 1458, 1462 (3d Cir 1990) (noting that Congress can grant courts discretion to consider particular circumstances of a case so as to toll a statute of limitations).

18 Morris v Government Development Bank of Puerto Rico, 27 F3d 746, 750 (1st Cir 1994).

1988 US (21 Wall) 342 (1875).

20 Id at 349-50.

21327 US 392 (1946).

22 Id at 397.

23 Wolin v Smith Barney Inc, 83 F3d 847, 852 (7th Cir 1989) (explaining that tolling is likely to arise in a fraud case). See also Weddel $v$ Secretary of Health and Human Services, 100 F3d 929, 931 (Fed Cir 1996) (stating that "[t]he doctrine of equitable tolling stops the running of the statute of limitation if, despite all due diligence, plaintiffs are unable to obtain essential information concerning the existence of their claim").

24 Irwin v Department of Veterans Affairs, 498 US 89, 96 (1990) (denying equitable tolling in "a garden variety claim of excusable neglect"). 
Title VII suits, ${ }^{25}$ habeas petitions, ${ }^{26}$ and Truth in Lending Act filings. ${ }^{27}$

Courts generally divide these "justifiable tolling" situations into two categories. In the first, the defendant has committed fraud or has fraudulently concealed the basis for the plaintiff's claim. ${ }^{28}$ In the second, extraordinary circumstances beyond the plaintiff's control prevent him from timely bringing his action. ${ }^{29}$ Into this latter "honest defendant" group fall such disparate cases as sudden military rule, ${ }^{30}$ a petitioner's insanity, a former attorney's leaving unusable work product for replacement counsel, ${ }^{32}$ and a petitioner whose mental incompetence rendered him unable to assist in his own defense. ${ }^{33}$ Equitable tolling has recently become very important in the immigrationdeportation context, where meeting a deadline can literally make the difference between remaining in the United States and deportation.

\section{B. Immigration and Nationality Act}

The INS conducts deportation proceedings pursuant to the Immigration and Nationality Act. ${ }^{34}$ Section $1229(\mathrm{a})(1)$ provides that in removal proceedings under Section 1229a, "written notice shall be given in person to the alien, or, if personal service is not practicable,

25 See Zipes $v$ Trans World Airlines, Inc, 455 US 385, 393 (1982) (finding that the filing deadline for a Title VII discrimination claim with the EEOC is subject to equitable tolling).

26 See Valverde $v$ Stinson, 224 F3d 129, 133 (2d Cir 2000) (holding that a habeas corpus petition may be equitably tolled under "extraordinary circumstances"). See also Helton $v$ Secretary for Department of Corrections, 233 F3d 1322, 1325-26 (11th Cir 2000) (finding that equitable tolling allowed consideration of untimely habeas petition).

27 See Ellis v General Motors Acceptance Corp, 160 F3d 703, 708 (11th Cir 1998) (finding statute of limitations in Truth in Lending Act subject to equitable tolling); Ramadan v Chase Manhattan Corp, 156 F3d 499, 504 (3d Cir 1998) (same).

28 See, for example, Barrett v United States, 689 F2d 324, 327-30 (2d Cir 1982) (tolling because defendant's fraudulent conduct prevented plaintiff from timely pressing his claim).

29 Bruce A. McGovern, The New Provision for Tolling Limitations Periods for Seeking Tax Refunds: Its History, Operation and Policy, and Suggestions for Reform, 65 Mo L Rev 797, 807 (2000) (discussing justifications for tolling).

30 See Forti v Suarez-Mason, 672 F Supp 1531, 1550-51 (N D Cal 1987) (tolling due to military seizure of power and subsequent restriction of access to fair adjudication).

31 See Nunnally v MacCausland, 996 F2d 1, 5 (1st Cir 1993) (allowing tolling of filing period due to mental illness); Hood $v$ Sears Roebuck and Co, 168 F3d 231, 232-33 (5th Cir 1999) (same).

32 See Calderon v United States District Court for the Central District of California, 128 F3d 1283,1289 (9th Cir 1997) (allowing tolling where petition was pursued diligently but work product was unusable by replacement counsel).

33 See Stoll v Runyon, 165 F3d 1238, 1242 (9th Cir 1999) (tolling in a sexual harassment case where alleged harassment impaired the plaintiff's ability to communicate with her male attorney).

348 USC $\S \S 1229$ et seq (1994 \& Supp 1999). 
through service by mail to the alien or the alien's counsel of record, if any."

Deportation is technically a civil proceeding, ${ }^{36}$ so there is no Sixth Amendment right to counsel, ${ }^{37}$ but the Act provides that "the alien shall have the privilege of being represented, at no expense to the Government, by counsel of the alien's choosing who is authorized to practice in such proceedings." ceeding, an alien shall have "a reasonable opportunity to examine the evidence against [him], to present evidence on [his] own behalf, and to cross-examine witnesses presented by the Government. ${ }^{, 39}$

These provisions clearly demonstrate that Congress was concerned with providing aliens with some Fifth Amendment due process protections, ${ }^{40}$ but Congress did not create unconditional privileges. If an alien fails to secure counsel within the allotted period, the Attorney General may initiate deportation proceedings against him despite his lack of representation. Similarly, if the INS gives an alien or his attorney notice per Section 1229(a) and the alien fails to attend his deportation hearing, he can "be ordered removed in absentia if the Service establishes by clear, unequivocal, and convincing evidence that the written notice was so provided and that the alien is removable., ${ }^{, 2}$

Once an IJ issues an in absentia deportation order, it may be rescinded in only two ways: upon a motion filed within 180 days if the failure to appear was due to "exceptional circumstances,", or "upon a

35 The removal proceedings are currently codified at 8 USC $\S 1229$ a (1994 \& Supp 1996). In 1996, Congress enacted the Illegal Immigration Reform and Immigrant Responsibility Act of 1996, Pub L No 104-208, 110 Stat 3009 (1996). Prior to this revision, Section 1229a had been codified almost verbatim at 8 USC $\S 1252 \mathrm{~b}$ (1994). The Act repealed Section $1252 \mathrm{~b}$ and recodified it at Section 1229a. 8 USC $\S 1229$ a (Supp 1996). Although the cases predating the Act refer to the deportation provision as Section $1252 \mathrm{~b}$, this Comment will refer to Section $1229 \mathrm{a}$ in all instances. The reader should treat them as synonymous.

36 See Woodby v INS, 385 US 276, 285 (1966) ("To be sure, a deportation proceeding is not a criminal prosecution."), citing Harisiades v Shaughnessy, 342 US 580, 594 (1952) ("Deportation, however severe its consequences, has been consistently classified as a civil rather than a criminal proceeding."); Rios-Berrios v INS, 776 F2d 859, 862 (9th Cir 1985) (noting that "a deportation hearing is not a criminal matter"); Robert Pauw, $A$ New Look at Deportation as Punishment: Why at Least Some of the Constitution's Criminal Procedure Protections Must Apply, 52 Admin L Rev 305, 307 (2000) (stating that "It]he order of deportation is not a punishment for crime"), citing Fong Yue Ting v United States, 149 US 698, 730 (1893).

37 US Const Amend VI ("In all criminal prosecutions, the accused shall enjoy the right ... to have the Assistance of Counsel.").

388 USC $\$ 1229 \mathrm{a}(\mathrm{b})(4)(\mathrm{A})$.

39 Id $\$ 1229 \mathrm{a}(\mathrm{b})(4)(\mathrm{B})$.

40 See Rios-Berrios, $776 \mathrm{~F} 2 \mathrm{~d}$ at 862 (holding under general Fifth Amendment principles that "[a]n alien is entitled to due process ... in his deportation hearing").

418 USC $\$ 1229(\mathrm{~b})(3)$.

42 Id $\S 1229 \mathrm{a}(\mathrm{b})(5)(\mathrm{A})$.

43 Id $\S 1229 a(b)(5)(C)(i)$. "Exceptional circumstances" are defined as those that are both compelling and "beyond the control of the alien," such as a serious illness or the death of a close family member. Id $\S 1229 a(e)(1)$. 
motion to reopen filed at any time if the alien demonstrates that the alien did not receive notice in accordance with . . . section 1229(a)."44 This Comment focuses on the 180-day filing deadline for an appeal based on exceptional circumstances.

\section{Approaches to the Filing Deadline for Exceptional Circumstances}

The courts' current views are quite fractious regarding equitable tolling's propriety in the in absentia context.

1. The Eleventh Circuit refuses to toll the filing deadline.

In Anin v Reno, an alien entered the United States on an "alien in transit" visa that allowed him to remain in the country for only one day. ${ }^{47} \mathrm{He}$ did not comply with his visa; in fact, he got married, and three years later filed for asylum and permanent residency status." Upon learning that Anin violated his visa's conditions, the INS sent notice of his deportation hearing to his attorney of record. ${ }^{49}$ Someone in the attorney's office signed the certified mail receipt, but neither Anin nor his attorney attended the hearing, and the attorney claimed he never received notice. ${ }^{51}$ Anin was ordered deported in absentia and taken into custody.

Meanwhile, Anin's attorney informed Anin that he would be able to reopen the case, and he filed an appeal predicated on lack of notice. ${ }^{53}$ The Immigration Judge held against Anin, but his attorney did not inform him of the adverse decision, and he discovered it only after the 180-day filing deadline had lapsed. ${ }^{54}$ Anin requested that the Board of Immigration Appeals ("BIA") toll the filing deadline based on ineffective assistance of counsel (an alleged "exceptional circumstance"), but it rejected his plea."

44 Id § 1229a(b)(5)(C)(ii).

45 Since there is no deadline for an appeal on the grounds of improper service, the equitable tolling doctrine discussed in this Comment has no potential application to those cases.

46188 F3d 1273 (11th Cir 1999).

47 Id at 1275 .

48 Id.

49 Id.

50 Id.

51 Id.

52 Id.

53 Id.

54 Id

55 Id. 8 USC $\$ 1229 \mathrm{a}(\mathrm{b})(5)(\mathrm{C})(\mathrm{i})$ states that an in absentia deportation order "may be rescinded only upon a motion to reopen filed within 180 days after the date of the order of removal if the alien demonstrates that the failure to appear was because of exceptional circum- 
On appeal, the Eleventh Circuit held that Section 1229a's 180-day filing deadline is "jurisdictional and mandatory," and therefore affirmed the BIA's denial of Anin's motion to reopen. Anin's jurisdictional interpretation adheres to the logic of most BIA decisions, which typically hold that when an alien files a tardy appeal, courts cannot entertain it. ${ }^{57}$

2. The First Circuit is receptive to arguments favoring tollability, but stresses a petitioner's diligence in pursuing his claim.

Two other circuits have refused to follow the Eleventh Circuit's lead. In Jobe $v$ INS ${ }^{58}$ the petitioner was an alien who spoke no English..$^{59} \mathrm{He}$ had authorization to stay in the United States for one month, but instead he stayed for approximately four, at which time he voluntarily contacted the INS and applied for political asylum. ${ }^{60}$ The INS denied his application and referred his case to an IJ for deportation proceedings. ${ }^{61}$ Jobe, through an intermediary, ${ }^{62}$ contacted an attorney to represent him at the hearing. The attorney requested a change of venue, and shortly before the hearing, he told Jobe that the court had granted the motion.

In reality, the court had denied the motion, and when neither Jobe nor his attorney attended the hearing, the IJ issued an in absentia deportation order. ${ }^{64}$ Jobe alleged that he knew nothing of this order until he filed an application to renew his employment authorization, at which time he could not retain new counsel and file an appeal before the 180-day deadline lapsed. ${ }^{65}$

The BIA dismissed Jobe's appeal, but a First Circuit panel, after extensive statutory analysis, explicitly rejected Anin's logic ${ }^{66}$ and held

56 Anin, $188 \mathrm{~F} 3 \mathrm{~d}$ at 1278.

57 See In re Lei, Interim Dec 3356, 1998 BIA LEXIS 23, *8 (reasoning that “[h]ad Congress intended to provide for an exception to the 180-day time limit based on the ineffective assistance of counsel, it could have done so"); In re A-A-, Interim Dec 3357, 1998 BIA LEXIS 22, *6 (holding that a claim of ineffective assistance of counsel does not constitute an exception to the 180 day filing deadline). The BIA hears appeals from Immigration Judges, and its decisions are appealed to the federal circuit court in whose jurisdiction the underlying events occurred.

58238 F3d 96 (1st Cir 2001) (en banc).

59 Id at 98.

60 Id at 97.

61 Id.

62 Because Jobe could not read, write, or speak English, he contacted a friend from his native country to arrange for legal representation. The friend retained an American attorney on Jobe's behalf. Id at 98 .

63 Id.

64 Id.

65 Id.

66 The initial opinion explained that Anin's "assertion that [ $\$ 1229$ a's] time limit is jurisdictional does not rest on any authority .... Nor does Anin contain any analysis of the statutory language." Jobe v INS, 2000 US App LEXIS 11607, *21 (1st Cir), withdrawn upon rehearing en 
that if "ineffective assistance of counsel can be [an] 'exceptional circumstance[ ]' excusing failure to appear, . . . in 'exceptional cases' it can also excuse failure to file a timely motion to reopen." ${ }^{57}$ Thus, it held that courts can equitably toll the filing deadline and remanded the case for further consideration of whether the ineffective assistance warranted such tolling.

The INS then sought and received a rehearing en banc, and the court withdrew the initial panel opinion. ${ }^{69}$ In the rehearing, the majority found that Jobe received oral notice of his deportation hearing through his friend only a month after the in absentia proceeding. ${ }^{70}$ It therefore held that despite his attorney's dereliction, Jobe's failure to take action "for more than half a year" following oral notice "conclusively establishes that [he] was insufficiently diligent ... to warrant the provision of any equitable relief." The court did not reach the question of whether the equitable tolling doctrine applies to Section 1229a.

The vigorous dissent, penned by the judge who wrote the initial panel opinion, argued that it is not "fair or just to deport an individual and put his life in danger on the basis of appellate fact-finding," and urged tolling on the same grounds as in the previous opinion." The majority signaled its receptiveness to that possibility in future cases, observing that the INS's jurisdictional argument "is skillfully countered ... by our dissenting brothers [and] the Massachusetts Law Reform Institute, which filed a well argued amicus brief." "73 Given an appropriately diligent petitioner, the First Circuit might well decline to follow the Eleventh Circuit's jurisdictional lead.

banc, 238 F3d 96. It concluded that "Lopez [is] more persuasive than Anin." Jobe, 2000 US App LEXIS 11607 at $* 21$.

67 Jobe, 2000 US App LEXIS 11607 at *24-25.

68 Id at *27. The Second Circuit also rejected Anin's logic in Iavorskiv INS, 232 F3d 124 ( $2 \mathrm{~d} \mathrm{Cir} 2000)$. In that case, the alien attended his hearing, but his attorney failed to file the promised appeal within the 90-day time limit established in 8 USC $\$ 1229 \mathrm{a}(\mathrm{c})(6)$ (A), the counterpart to the in absentia provision. Iavorski, $232 \mathrm{~F} 3 \mathrm{~d}$ at 127 . Although Iavorski did not concern an in absentia appeal, it nonetheless noted that $A$ nin's finding of a jurisdictional limit in the sister statute was "without explanation," id at $130 \mathrm{n} 5$, and held that the "accommodation for exceptional cases is irreconcilable [ ] with the strict application that would be required of a jurisdictional limitation." Id at 132.

\footnotetext{
69 Jobe, $238 \mathrm{~F} 3 \mathrm{~d}$ at 99.

70 Id at $100-01$.

71 Id at 101.

72 Id at 106.

73 Id at 99-100.
} 
3. The Ninth Circuit considers a representative's fraud sufficient to toll the filing deadline.

Finally, in a pre-Anin case, Lopez $v$ INS ${ }^{74}$ a notary public posing as an immigration attorney defrauded an alien, who did not recognize the deceit until after the filing deadline had lapsed. ${ }^{75}$ The Ninth Circuit, following the approach rejected in Anin, explained that "where a plaintiff has been injured by fraud and 'remains in ignorance of it without any fault or want of diligence or care on his part, the bar of the statute does not begin to run until the fraud is discovered.","76 It then held that "the statute of limitations to reopen an order of deportation is equitably tolled where the alien's late petition is the result of the deceptive actions by a notary posing as an attorney." "n

Thus, among the three circuits to address the question of when courts should equitably toll Section 1229 a's filing deadline, there are three degrees of tolling support. The Eleventh Circuit holds that the deadline is a non-tollable jurisdictional limit; the First Circuit indicates that the deadline might be tollable if a petitioner is suitably diligent; and the Ninth Circuit holds that alleged fraud is one clearly sufficient reason to toll.

\section{THE 180-DAY APPEALS DEADline Is PROPERLY VIEWED AS A TOLLABLE STATUTE OF LIMITATION}

Although Anin held that Section 1229a is a jurisdictional limit, Supreme Court precedent and statutory interpretation demonstrate that it is better viewed as a tollable statute of limitation. In Irwin v Department of Veterans Affairs, ${ }^{78}$ the Court noted that there is a "rebuttable presumption" that equitable tolling applies to federal statutes," and nothing in the INA rebuts this presumption. The statute contains no specific tolling provision, suggesting that Congress did not want to override the normal pro-tolling presumption, nor does the statute contain detailed or emphatic language. Indeed, it is linguistically similar to numerous other statutes that courts have held equitably tollable.

Similarly, the legislative history and statutory purpose evince no congressional intent to limit courts' equitable powers. The history demonstrates a clear concern with prosecutorial fairness and individual equities, and while the statute's purpose includes preventing collu- 
sive obstruction, Congress did not intend to limit courts' presumed powers to redress injustice. Given this evidence, Anin's jurisdictional conclusion seems mistaken.

\section{A. Classifying the Filing Deadline As Jurisdictional or Prudential}

Before an Article III court may hear a case on its merits, it must satisfy itself of its subject matter jurisdiction. ${ }^{80}$ It is therefore critical to determine whether Section 1229a's filing deadline is a jurisdictional limit or merely a prudential statute of limitations. If the deadline is a jurisdictional limit, Congress has not granted courts the power to adjudicate claims beyond that date, and tolling the deadline to reach an appeal's merits would thus raise serious constitutional concerns. If the deadline is merely a prudential statute of limitations, however, equitable tolling is possible since it implicates no expansion of judicial power.

Since courts cannot toll jurisdictional deadlines, a congressional intent to allow tolling would strongly suggest that Congress did not intend to restrict courts' jurisdiction. Congressional intent is thus of central concern, and the Court has provided guidance for interpreting it in this context. In United States $v$ Locke, the Court noted that "[s]tatutory filing deadlines are generally subject to the defense of ... equitable tolling," "rebuttable presumption" that equitable tolling applies to suits against both private defendants and the United States.

Most recently, in United States $v$ Brockamp, the Court succinctly summarized the state of the law. A court confronting the issue of whether a filing deadline is tollable must ask Irwin's negatively phrased question: "Is there good reason to believe that Congress did not want the equitable tolling doctrine to apply?"

Anin did not explain its jurisdictional reasoning, and the court of appeals case on which it relied, Kamara $v I N S{ }^{87}$ provides scant support for its position. In Kamara, the Eighth Circuit held that the BIA "did not err" in denying as time barred a tardy motion to reopen. ${ }^{88}$ The court nowhere termed the deadline jurisdictional, nor did it hold that

80 See Ruhrgas $A G$ v Marathon Oil Co, 526 US 574, 577 (1999) (noting that Article III courts must have subject matter jurisdiction before they may entertain a suit on its merits).

81 See Rotella $v$ Wood, 528 US 549, 560 (2000) (noting the settled "understanding that federal statutes of limitations are generally subject to equitable principles of tolling").

82471 US 84 (1985).

83 Id at $94 \mathrm{n} 10$.

84 Irwin, 498 US at $95-96$.

85519 US 347 (1997).

86 Id at 350.

87149 F3d 904 (8th Cir 1998).

88 Id at 906. 
equitable modification was beyond its power. As such, Anin's jurisdictional holding goes far beyond Kamara's, and neither opinion defends its ultra-formalistic statutory interpretation in a setting where the Court normally presumes equitable powers.

\section{B. There Is Little Textual Evidence That Congress Intended to Foreclose Equitable Tolling}

With the "tolling presumption" in mind, the next step is to evaluate Section 1229a's 180-day filing deadline to determine whether Congress intended to foreclose equitable tolling. Although courts historically employed a substance-procedure dichotomy to evaluate equity's proper role in a statute, ${ }^{89}$ the modern approach is to evaluate congressional intent..$^{90}$ In doing so, courts "consider[ ] the language of the statute, [its] legislative history, and [its] statutory purpose.",

The first step, then, in deciding whether courts can toll the 180day deadline, is to examine the language in Section $1229 \mathrm{a}^{92}$ As the Court stated in Locke, "with respect to filing deadlines a literal reading of Congress' words is generally the only proper reading of those words." scinded only upon [an 'exceptional circumstances'] motion to reopen filed within 180 days after the date of the order of removal." language does not suggest a congressional intent clear enough to override the presumption that courts retain equitable powers. ${ }^{95}$

Section 1229a's language is also not very emphatic, simply employing the word "only" as a limiting factor. ${ }^{\% 6}$ This is suggestive, because "[t]he presence of especially emphatic language in a time limitation can be determinative of congressional intent to disallow equitable modification. It follows that the absence of such language, while not

89 See David D. Doran, Comment, Equitable Tolling of Statutory Benefit Time Limitations: A Congressional Intent Analysis, 64 Wash L Rev 681, 684 (1989) (describing the evolution of equity's role in statutory analysis). See also Burnett v New York Central Railroad Co, 380 US 424, 426-27 n 2 (1965) (discussing procedural-substantive dichotomy).

90 See Doran, Comment, 64 Wash L Rev at 686 (cited in note 89).

91 Miller v New Jersey State Department of Corrections, 145 F3d 616, 618 (3d Cir 1998), citing Shendock v Director, Office of Workers' Compensation Programs, 893 F2d 1458, 1462-64 (3d Cir 1990).

92 See Good Samaritan Hospital v Shalala, 508 US 402, 409 (1993) ("The starting point in interpreting a statute is its language, for if the intent of Congress is clear, that is the end of the matter."); Davis v Johnson, 158 F3d 806, 810-11 (5th Cir 1998) ("The clearest indication of congressional intent is the words of the statute itself.").

93471 US at 93.

948 USC $\$ 1229 \mathrm{a}(\mathrm{b})(5)(\mathrm{C})(\mathrm{i})$.

95 See text accompanying notes 83-86. See also Hecht Co $v$ Bowles, 321 US 321, 330 (1944) (expressing the Court's belief that "if Congress desired to make [ ] an abrupt departure from traditional equity practice[ ], it would have made its desire plain").

96 "Such an order may be rescinded only upon a motion filed within 180 days." 8 USC $\S 1229 \mathrm{a}(\mathrm{b})(5)(\mathrm{C})(\mathrm{i})$. 
dispositive, is one factor suggesting an intent to allow equitable modification."

Paralleling this lack of emphasis is a lack of detail. This suggests that Congress likely intended courts to interpret the statute with the usual presumptions. In Brockamp, for example, the Supreme Court held that very detailed statutory language that "linguistically speaking, cannot easily be read as containing explicit exceptions" can signal jurisdictional intent. ${ }^{98}$ The Court, however, also held that the opposite can be true, suggesting that a statute requiring a claim to be filed "within 90 days of receipt of notice of final action" might contain an implied equitable tolling exception."

Finally, analogy to other interpreted statutes yields strong support for equitable tolling. In Burnett $v$ New York Central Railroad Co, ${ }^{100}$ the Supreme Court held tollable a statute providing that "no action shall be maintained ... unless commenced within three years from the day the cause of action accrued." Similarly, in William G. Tadlock Construction $v$ United States Department of Defense, ${ }^{102}$ the Ninth Circuit held tollable a statute providing that a "complaint may not be filed more than 180 days after the later of the date on which the violation is alleged to have occurred or was discovered."103 Both of these statues seem linguistically similar to Section 1229 a, and both were held to allow equitable modification. Section 1229a's mere "exceptional circumstance" language cannot transform a statute of limitations into a jurisdictional bar.

One might challenge this conclusion of tollability in three ways, though none is persuasive. The first is that because Congress provided a 180-day appeal window, it might have intended this to be the exclusive concession to equity. ${ }^{104}$ Under this view, if Congress had intended courts to use their presumed equitable powers, it would have explicitly

97 Cynthia Reed, Note, Time Limits for Federal Employees under Title VII: Jurisdictional Prerequisites or Statutes of Limitation?, 74 Minn L Rev 1371,1399-1400 (1990) (discussing statutory interpretation in the Title VII context).

98519 US at 350.

99 Id.

100380 US 424 (1965).

101 Id at 426, quoting 45 USC $\$ 56$ (1994) (providing the limitations period under the Federal Employer's Liability Act).

10291 F3d 1335 (9th Cir 1996).

103 Id at 1340 (concerning an action under former 10 USC $\$ 2409$ a).

104 See, for example, United States v Beggerly, 524 US 38, 48 (1998) (holding that by providing that the statute of limitations will not begin to run until the plaintiff "knew or should have known of the claim of the United States," Congress already effectively allowed for equitable tolling). The statute at issue in Beggerly is materially different from Section 1229a, because unlike Section 1229a, it requires a plaintiff to have a subjective awareness of his cause of action before the statute of limitations begins to run. In such situations, courts might more easily conclude that since Congress ensured a plaintiff's claim will not be time barred absent some neglect on his part, it intended to foreclose further equitable measures. 
allowed for equitable modification of the deadline where justice so requires.

There is no particular reason why this reasoning should hold, however. After all, the very existence of the appeal section indicates that Congress was at least somewhat concerned with equity, and the legislative history makes this concern explicit. ${ }^{105}$ It is therefore equally plausible that Congress intended the appeal window to be a minimum guarantee of equity. ${ }^{106}$

The second possible attack on Congress's "equitable intent" is the common refrain that if Congress wanted the deadline to be tollable, it would have stated so explicitly. The BIA subscribes to this analysis in construing Section $1229 \mathrm{a},{ }^{107}$ but it is a very tenuous interpretation. The Supreme Court has cautioned against using precisely this kind of negative inferential reasoning because such "excursion[s] into extrapolation of legislative intent are most often entirely unilluminating." 108 Indeed, given Irwin's stated assumption that courts can equitably toll absent language to the contrary, Congress's omission might simply reflect the application of legislative economy.

Lastly, an expressio unius interpretation might suggest that since the INA considers timely a motion to reopen "filed at any time if the alien demonstrates that the alien did not receive notice,"109 Congress's failure to include similar flexibility for "exceptional circumstance" appeals evinces its intent to deny all such motions. This is highly unlikely given Irwin's tolling presumption-if Congress wished to restrict courts' jurisdiction, it would not have expressed that intent only through subtle linguistic differentiation. ${ }^{110}$ Moreover, even if Congress expected courts to use expressio unius logic to hold tardy appeals meritless, that does not imply that Congress intended to restrict courts' jurisdiction to entertain such motions. Quite the opposite, if Congress wanted lower courts to deny tardy appeals on their merits, it must have intended that lower courts have jurisdiction to reach those merits. Generally, then, the statutory language does little to rebut the presumption that the filing deadline is a statute of limitations rather than a jurisdictional limit, and this in turn suggests that courts have the power equitably to toll the 180 -day filing deadline.

105 See Part II.C.

106 See Jobe, 2000 US App LEXIS 11607 at *14-15 (noting that statutory language might be an "equitable safety valve provision").

107 In re $A$ - $A$-, Interim Dec 3357, 1998 BIA LEXIS 22, *8.

108 Calderon v United States District Court for the Central District of California, 128 F3d 1283, 1289 (9th Cir 1997), quoting Cort v Ash, 422 US 66, 83 n 14 (1975).

1098 USC $\$ 1229$ a(b)(5)(C)(ii).

110 See note 95 . 


\section{The INA's Legislative History Evinces a Congressional Desire for Equity, Rather Than an Intent to Curb Courts' Equitable Powers}

Although the INA's legislative history is somewhat scant, it also supports the idea that the filing deadline is a tollable statute of limitations. Equity clearly concerned the Conference Committee during the Act's 1990 revision." The conferees explained that they "expect that in determining whether an alien's failure to appear was justifiable the Attorney General will look at the totality of the circumstances to determine whether the alien could not reasonably have been expected to appear." ${ }^{\text {"112 }}$ Similarly, in the Conference on the original 1952 Act, the record states that "the conferees have refined the language so as to make it emphatically clear that the Attorney General may not ... capriciously deport an alien solely on the basis of inconsequential, unwitting infraction[s] of the law." ${ }^{113}$

Strictly speaking, neither conference report discusses the equitable powers of courts to toll a filing deadline; instead, both concern themselves with ensuring evenhanded prosecution. This may suggest that Congress preferred for the Justice Department to exercise prosecutorial discretion rather than for the judiciary to exercise adjudicative discretion. Given the Court's past equitable presumptions and Congress's clear desire to prevent inequity, however, it is more likely that Congress was concerned that prosecutorial discretion would be insufficient to check the harshness of deportation. Indeed, the mere fact that the history does not mention jurisdiction may suggest that Congress did not wish to limit courts' equitable powers. ${ }^{114}$ Thus, far from foreclosing Congress's intent to allow equitable tolling, the legislative history signals a strong congressional concern for ensuring

111 A recent legislation treatise notes that committee reports "should be considered as authoritative legislative history and should be given great weight .... Most legislation is essentially written in committee or subcommittee, and any collective statement by the members of that subgroup will represent the best-informed thought about what the proposed legislation is doing." William N. Eskridge, Jr. and Philip P. Frickey, Cases and Materials on Legislation: Statutes and the Creation of Public Policy 743 (West 2d ed 1995). For example, in Schwegmann Brothers v Calvert Distillers Corp, 341 US 384, 395 (1951) (Jackson concurring), Justice Jackson objected generally to the use of legislative materials as interpretive tools, but he excepted committee reports from his quarrel.

112 Immigration Act of 1990, Joint Explanatory Statement of the Committee of Conference, HR Rep No 101-955, 101st Cong, 2d Sess 132 (Oct 26, 1990), reprinted in 1990 USCCAN 6797.

113 Immigration and Nationality Act, Conference Report, HR Rep No 82-2096, 82d Cong, 2d Sess (June 9, 1952), in 98 Cong Rec H 6986 (June 10, 1952), reprinted in 1952 USCCAN 1754, 1754.

114 See Miller $v$ New Jersey State Department of Corrections, 145 F3d 616,618 (3d Cir 1998) (concluding that where congressional conference report did not refer to jurisdiction and various members of Congress referred to the period as a statute of limitations, habeas corpus statute was subject to equitable tolling). 
broad equitable treatment and evenhanded prosecution in deportation proceedings.

\section{The INA's Statutory Purpose Does Not Imply an Intent to Curb Courts' Equitable Powers}

Finally, like its text and history, the INA's statutory purpose does not suggest a congressional intent to curb courts' equitable powers. The in absentia deportation procedure was developed in the original Act in order to prevent obstructionist tactics, ${ }^{115}$ and the Conference Report to the 1990 amendments recognizes that "willful and unjustifiable failure to attend deportation hearings that have been properly noticed is intolerable." Congress's concern with obstructionist tactics evinces an "intent to bring finality to in absentia deportation proceedings." ${ }^{117}$ The implicit logic is that since the in absentia procedure is designed to bring finality and prevent stalling tactics, Congress likely did not intend to allow courts to undermine that finality by equitably tolling the deadline for filing an appeal.

This logic is ultimately unconvincing. Congress's intent to bring closure to deportation proceedings is an argument on the merits against tolling generally, but it hardly constitutes clear evidence that Congress intended to restrict courts' power to hear legitimately tardy appeals. There is a significant qualitative difference between allowing the Attorney General to proceed in absentia against aliens who refuse to appear despite proper service, and restricting courts' power to hear appeals that are tardy only due to fraud or attorney incompetence."

Finally, although there are often compelling purposive reasons why Congress would make a deadline a jurisdictional limit instead of a statute of limitations, no such reason is persuasive in the deportation setting. For example, in Brockamp, the Supreme Court held that the

115 See Report from the Committee on the Judiciary, HR Rep No 82-1365, 82d Cong, 2d Sess 57 (Feb 14, 1952), reprinted in 1952 USCCAN 1712-13:

Orderly administrative processes have at times been interrupted and subjected to unnecessary delays because aliens, without legitimate cause, refused to attend scheduled hearings or insisted upon leaving at their own pleasure and without other than contumacious reasons. The Government should have authority to proceed to a final decision in the face of such obstructionist tactics.

116 Report from the Committee on the Judiciary, HR Rep No 101-681, 101st Cong, 2d Sess 150 (Sept 5, 1990), reprinted in 1990 USCCAN 6556. See also Romero-Morales v INS, 25 F3d 125,128 (2d Cir 1994) (discussing the statutory purpose of the INA's 1990 amendments).

117 In re $A-A-$, Interim Dec 3357,1998 BIA LEXIS $22,{ }^{*} 6$.

118 See, for example, Lopez, 184 F3d at 1097 (concerning a notary public fraudulently posing as an attorney skilled in immigration law); Jobe, $238 \mathrm{~F} 3 \mathrm{~d}$ at 63 (concerning an attorney who assumed that a motion for change of venue would be granted, and instructed his client that he need not attend the originally scheduled hearing). 
equitable power to toll a tax filing deadline could not be read into the Internal Revenue Code. ${ }^{119}$ It reasoned that Congress wished to protect itself against stale monetary claims, ${ }^{120}$ and to allow tolling would be to subject the IRS to the immense administrative difficulties inherent in responding to millions of claims annually. ${ }^{121}$ The Court also noted that "[t]ax law ... is not normally characterized by case-specific exceptions reflecting individualized equities."

Similarly, in United States $v$ Beggerly, ${ }^{123}$ the Supreme Court held that the Quiet Title Act's filing deadline was a jurisdictional limit." Key to its reasoning was that "[i]t is of special importance that landowners know what their rights are, and the period during which those rights may be subject to challenge. Equitable tolling ... would throw a cloud of uncertainty over these rights." ${ }^{125}$ These situations clearly reflect the previously discussed ${ }^{126}$ tolling tradeoff between ensuring individual equities, on the one hand, and preserving potential defendants' "right[s] to be free of stale claims"

The arguments favoring finality in tax, quiet title, and bankruptcy settings are not equally persuasive in deportation cases. Unlike tax law, immigration law is undeniably concerned with individual circumstances: the Conference Report in 1990 emphasized that "the Attorney General will look at the totality of the circumstances to determine whether the alien could not reasonably have been expected to appear." ${ }^{128}$ This language clearly contemplates examining the facts in each individual case.

Moreover, unlike in quiet title and bankruptcy proceedings, the government has no pressing need to protect itself from stale deportation claims. In a quiet title action, for example, the government has a clear need to know when its land is no longer subject to a potential adverse claim. Deportation proceedings typically do not implicate significant physical or monetary claims against the government, ${ }^{129}$ so

119519 US at 353-54.

120 Id at 353.

121 Id at 352 .

122 Id.

123524 US 38 (1998).

124 Id at $42-49$.

125 Id at 49. See also Schunck v Santos, 112 BR 1001, 1006 (BAP 9th Cir 1990), quoting In re Harrison, 71 BR 457, 459 (Bankr D Minn 1987) (finding that bankruptcy filing limits are not tollable because they serve "the 'fresh start' goals of bankruptcy relief [that allow] a debtor to 'enjoy finality and certainty in relief from financial distress as quickly as possible"').

126 See text accompanying notes $13-16$.

127 Burnett, 380 US at 428.

128 HR Rep No 101-955 at 132 (cited in note 112) (emphasis added).

129 Although it is possible that an alien may receive welfare benefits or other resources, this additional claim likely will be minor in the case of a short-term missed deadline. In no circuit case on this subject does a court concern itself with this potential outlay. 
Congress's need to ensure finality is not as pressing. At worst, the alien may remain in the country for longer than he might have otherwise, but the potential inconvenience from this extended stay does not convincingly outweigh Congress's explicit desire to take account of individual circumstances in deportation proceedings. ${ }^{130}$ As the Second Circuit recently explained, "immigration law in general possesses no special [limited] status where equitable tolling is concerned. . . . Indeed, the more far-reaching equitable remedy of granting relief nunc pro tunc in certain exceptional cases has long been available under immigration law." ${ }^{131}$ If Congress intended to break from this equitable tradition, it would likely have stressed that intent.

\section{The Proposed Solution: Courts Should TOLl THE 180-DAY FILING DEADLINE ONLY IF AN ALIEN'S ATTORNEY AFFIRMATIVELY MISLEADS HIM}

Many of the cases that come before the Board of Immigration Appeals involve situations where an alien alleges that he was not informed of the date of his initial deportation hearing. ${ }^{132}$ This is not usually the INS's fault, at least not directly; rather, the INS often sends notice to an alien's attorney of record, and the attorney sometimes fails accurately to disseminate that information to his client. ${ }^{133}$ In some of these cases, the attorney fails to convey any notice at all, and in such circumstances, it would be surprising for an alien to learn of the missed hearing in time to meet the appeal deadline.

In other cases, an alien's attorney conveys the original notice to the alien, but he subsequently misinforms him of material facts relating to that hearing. Sometimes this is clear fraud, ${ }^{134}$ such as in Lopez, where a notary public posing as an attorney told his "client" that he need not attend his hearing. ${ }^{135}$ Lopez had received independent notice, ${ }^{136}$ but he trusted the fraudulent advice. In many such misinforma-

130 See text accompanying note 112 .

131 Iavorski v INS, 232 F3d 124, 130 n 4 (2d Cir 2000), citing Batanic v INS, 12 F3d 662, 66768 (7th Cir 1993) (permitting submission of otherwise barred application for asylum).

132 See, for example, In re $A-A$-, Interim Dec 3357, 1998 BIA LEXIS 22, *2-3 (concerning situation where respondent claimed he never received notice from his attorney).

133 See id (noting that someone in the attorney's office had signed the notice's certified mail receipt); In re Lei, Interim Dec 3356, 1998 BIA LEXIS 23 (concerning a similar situation where an attorney allegedly received notice of the original hearing, but not the rescheduled hearing).

134 To the extent that aliens may be less familiar with the English language and American judicial system than are American citizens, they might be particularly deferential to attorney advice and thus more vulnerable to fraud of this kind.

$135184 \mathrm{~F} 3 \mathrm{~d}$ at 1099.

136 Id. 
tion cases, however, the attorney simply predicates his advice on a negligent procedural mistake.

This Comment proposes that when the INS properly serves notice but an alien does not attend his deportation hearing, courts should draw a misfeasance-nonfeasance distinction and equitably toll only if the alien alleges that his attorney made material misrepresentations that proximately caused his absence and failure to file a timely appeal. Under this approach, courts should toll regardless of whether the alleged misinformation is due to attorney fraud or negligence, but allegations of a nonfeasant failure to relay notice should not warrant tolling.

\section{A. An Attorney's Misfeasance Has Severe Consequences That Should Justify Tolling the Filing Deadline}

Mere attorney negligence is not usually considered an "exceptional circumstance" justifying rescission of an in absentia deportation order. ${ }^{138}$ As discussed in Part I, the INA explains that an "exceptional circumstance" is one "such as serious illness of the alien or serious illness or death of the spouse, child, or parent of the alien, but not including less compelling circumstances," and mandates that the circumstances be "beyond the control of the alien." "139

Since an exceptional circumstance must be beyond the alien's control, not just any situation is sufficient to justify equitable tolling. Statutes of limitations are harsh by nature, ${ }^{140}$ and judges cannot soften this harsh outcome out of mere sympathy. ${ }^{141}$ Courts have themselves employed equitable tolling only grudgingly - the Supreme Court has held that the principle "do[es] not extend to what is at best a garden variety claim of excusable neglect," $" 142$ and other courts have held that ignorance of legal rights, ${ }^{143}$ illiteracy, ${ }^{144}$ and lack of representation ${ }^{145}$ are insufficient bases for tolling.

137 See, for example, Patel $v$ INS, 803 F2d 804, 806 (5th Cir 1986) (concerning a situation where an attorney suggested that an alien need not attend his deportation hearing based on the attorney's expectation that his motion for a continuance would be granted).

138 See Taliani v Chrans, 189 F3d 597, 598 (7th Cir 1999) (Posner) ("Normally, [ ] a lawyer's mistake is not a valid basis for equitable tolling.").

1398 USC $\S 1229 \mathrm{a}(\mathrm{e})(1)$.

140 Parker and Colella, 29 Seton Hall L Rev at 886 (cited in note 11) ("Limitation periods are by their very nature harsh because they cut off a person's rights without regard to the merits of the claim.").

141 See Locke, 471 US at 95 ("Nor is the Judiciary licensed to attempt to soften the clear import of Congress' chosen words whenever a court believes those words lead to a harsh result.").

142 Irwin, 498 US at 96.

143 See Larson v American Wheel and Brake, Inc, 610 F2d 506, 510-11 (8th Cir 1979) (concluding a defendant was entitled to summary judgment where the plaintiff failed to file a timely notice of intent to sue with the Secretary of Labor). 
A primary reason for judicial reluctance to toll is that tolling has the strong potential to encourage obstructionist tactics. ${ }^{146}$ If minor attorney error is sufficient to invoke equitable tolling, the attorney and client might collusively obstruct proceedings by intentionally committing minor errors in order to gain time. ${ }^{147}$ Indeed, there is clear evidence that the drafters of the original Act intended to eradicate such tactics.

Despite these valid reservations, ${ }^{149}$ however, courts have considered cases of active attorney misrepresentation to be "exceptional circumstances" justifying rescission of an order. In In re Grijalva, ${ }^{1,0}$ for example, an alien's attorney called on the morning of his hearing and falsely told him that the court had granted a continuance. ${ }^{151}$ The BIA had no trouble finding that "the level of incompetence ... establishes that the respondent's absence was the result of exceptional circumstances .... [He] was blatantly misled regarding his need to appear at the scheduled hearing." failure to appear at the original deportation hearing, it seems only appropriate that active misrepresentation should also be grounds for equitably tolling the deadline for filing exceptional circumstance appeals. There are several reasons for this conclusion, but the clearest is based upon result. Courts traditionally view deportation as a civil proceeding, ${ }^{153}$ and as such, a potential deportee's rights are not nearly as extensive as a criminal defendant's. ${ }^{1.4}$ This view, however, undervalues deportation's incredible harshness and punitive nature. As the Supreme

144 See Barrow v New Orleans Steamship Association, 932 F2d 473, 478 (5th Cir 1991) (concluding that since ignorance of legal rights does not toll statute of limitations, it is irrelevant whether that ignorance was due to illiteracy).

145 See James $v$ United States Postal Service, 835 F2d 1265, 1267 (8th Cir 1988) (concluding that where noncompliance with statute of limitations results from claimant's inability to find a lawyer or unfamiliarity with legal process, there is no justification for equitable relief).

146 See INS v Rios-Pineda, 471 US 444, 450 (1985) (noting “incentive for stalling”).

147 See In re Rivera, I \& N Dec 599, 604 (BIA 1996) (protecting against attorney-client obstructive collusion).

148 See note 115 .

149 See Part III.C for a discussion of why collusive obstruction is not a compelling concern.

150 In re Grijalva, Interim Dec 3284, 1996 BIA LEXIS 22.

151 Id at *3.

152 Id at *6.

153 See note 36.

154 Robert Pauw explains:

[A] person facing deportation does not have a right of trial by jury; there is no Sixth Amendment right to the assistance of counsel; the exclusionary rule under the Fourth Amendment does not apply; the Ex Post Facto Clause does not apply; no limits to deportation are imposed by virtue of the Double Jeopardy Clause; the Eighth Amendment's prohibition against cruel and unusual punishment is not relevant; and the Bill of Attainder Clause does not apply.

Pauw, 52 Admin L Rev at 309-10 (cited in note 36). 
Court itself has recognized, "[deportation] visits a great hardship on the individual and deprives him of the right to stay and live and work in this land of freedom. That deportation is a penalty-at times a most serious one-cannot be doubted."15s Another court agreed, asking rhetorically,

How can deportation of an alien legally residing in the United States be considered anything but punishment? [The] petitioner stands to lose his residence, livelihood, and most importantly, his family. Certainly if the same thing occurred to a United States citizen a court would not hesitate to call it punishmentmoreover, cruel and unusual punishment. ${ }^{15 \%}$

Given deportation's overwhelming seriousness, grave consequences, and explicitly recognized penal nature, ${ }^{157}$ equitable safeguards are plainly necessary. The Supreme Court has expressed concern with a lay citizen's ability to mount an effective pro se legal defense. ${ }^{1.58}$ If a typical American citizen cannot effectively defend himself, an alien who may have less familiarity with the language and judicial system is likely no more capable, and a court should not expect him to assess accurately his attorney's procedural acumen. If an alien's attorney tells him that he need not attend a hearing, a court should not penalize him for heeding that advice, regardless of whether the attorney is fraudulent or merely negligent.

This logic dictates that when an alien alleges that his attorney's misinformation proximately caused him to miss his hearing and Section 1229a's appeals deadline, a court should equitably toll to reach the merits of whether the ineffective assistance constituted an exceptional circumstance. Tolling is thus appropriate in cases such as Patel $v$ $I N S,{ }^{160}$ where an attorney allegedly informed his client that the court

155 Bridges $v$ Wixon, 326 US 135, 154 (1945).

156 Lieggi v INS, 389 F Supp 12, 17 (N D Ill 1975), revd 529 F2d 530 (7th Cir 1976). See also Pauw, 52 Admin L Rev at 326 (cited in note 36); Jack Wasserman, Grounds and Procedures Relating to Deportation, 13 San Diego L Rev 125, 128 (1975) ("Our immigration statute exhibits an unyielding, unforgiving and vengeful attitude toward those who have sinned and been rehabilitated.").

157 See text accompanying notes $155-56$.

158 See Gideon v Wainwright, 372 US 335, 344 (1963), quoting Powell v Alabama, 287 US 45, 68-69 (1932):

The right to be heard would be, in many cases, of little avail if it did not comprehend the right to be heard by counsel.... [A layman] lacks both the skill and knowledge adequately to prepare his defense, even though he have a perfect one. He requires the guiding hand of counsel at every step in the proceedings against him.

159 This admittedly raises the specter of potential collusion, but Part III.C suggests that this is not of compelling concern.

160803 F2d 804 (5th Cir 1986). 
would automatically grant a continuance, ${ }^{161}$ and Lopez, where a notary public allegedly defrauded an alien and told him not to attend his hearing. ${ }^{162}$ This approach allows for equitable considerations without giving rise to the problems that statutes of limitations are designed to avoid.

\section{B. Reconciling Limited Tolling with the INA's Notice Provision}

Some might claim that since serving notice to an attorney is tantamount to serving his client, any tolling is improper if the INS properly serves an alien's attorney. This argument has some textual support. First, the INA states that "[i]n removal proceedings under [Section 1229a], written notice shall be given in person to the alien (or, if personal service is not practicable, through service by mail to the alien or to the alien's counsel of record)." "Second, the Code of Federal Regulations ("CFR") provides that "[w]henever a person is required ... to give or be given notice ... such notice... shall be given by or to ... the attorney or representative of record, or the person himself if unrepresented." ${ }^{164}$

The entire point of equitable tolling, however, is that it allows equitable intervention to avoid prejudice that falls outside the existing statutory framework. Congress clearly wished to prevent aliens from being deported "solely on the basis of inconsequential, unwitting infraction[s] of the law," ${ }^{165}$ and few things seem less witting than an alien's failure to attend a hearing because his attorney so instructed him. Especially given deportation's overwhelming harshness, ${ }^{166}$ such situations seem ripe for equitable intervention. As one judge argues,

[i]t is difficult to imagine what could be more prejudicial to a respondent charged with being deportable from the United States than denial of an opportunity to be present at his deportation hearing where he might provide any defenses to the charges against him, or advance any claims he may have for relief from deportation."

This concern is consonant with the INA itself, which provides that an alien "shall have a reasonable opportunity to examine the evidence against [him], to present evidence on [his] own behalf, and to cross-

161 Id at 806 .

162184 F3d at $1098-99$.

1638 USC $\$ 1229$ (a)(1). Note that this provision actually prefers service on an alien and allows service on the alien's attorney only when the alien is unreachable.

164 8 CFR $\$ 292.5(a)$ (2000).

165 See note 113.

166 See text accompanying notes 154-156

167 In re $A \cdot A \cdot$, Interim Dec 3357,1998 BIA LEXIS 22, *10-11 (Rosenberg concurring in part and dissenting in part). 
examine witnesses." 168 The CFR prefers serving attorneys, but that should not deter courts from fulfilling their envisioned equitable role when the system breaks down-indeed, that is the precise purpose of equitable tolling. ${ }^{169}$

\section{Collusive Behavior is Not a Substantial Threat}

There is, however, some reason to doubt the wisdom of generously applying equitable tolling to cases of attorney error. One reason for hesitation is that equitable tolling typically applies only where there is positive misconduct by the party against whom it is asserted. ${ }^{170}$ In none of the cited cases involving attorney mistake is the INS directly at fault; therefore, employing equitable tolling in cases of attorney error would significantly extend the doctrine.

Moreover, this relatively liberal approach to tolling might increase the opportunity for collusion between an alien and his attorney. Although this is reason for caution, several factors suggest that collusion problems are unlikely to outweigh the need to provide potential deportees with equitable treatment. First, and perhaps most importantly, the INS provides for severe penalties, including fines, permanent expulsion from the immigration bar, and recommendation of disbarment, ${ }^{171}$ for a virtual laundry list of unethical, unprofessional, and frivolous actions, including for any reason "in the public interest.", Certainly collusive behavior would merit such sanction. It is unlikely that any attorney is willing to risk his career simply to delay a deportation proceeding.

Second, it is unclear precisely what material advantage an attorney and his client would gain from delaying a deportation hearing. To be sure, an alien might remain in the country beyond 180 days, but it strains credibility to think that this could be a permanent solution. Equitably tolling the filing deadline does not allow an alien completely to avoid a hearing. Especially given the previously discussed sanctions, it seems unlikely that an attorney would think any minor gain from delay would outweigh the risk.

1688 USC $\$ 1229 \mathrm{a}(\mathrm{b})(4)(B)$.

169 See Part I.A.

170 See Thomas S. Rue, Admiralty, 45 Mercer L Rev 1175, 1176 (1994), quoting Irwin, 498 US at 96 (explaining that equitable tolling is allowed "where the complainant has been induced or tricked by his adversary's misconduct into allowing the filing deadline to pass"); Anderson v Unisys Corp, 47 F3d 302, 306 (8th Cir 1995) (noting that "[e]quitable tolling arises upon some positive misconduct by the party against whom it is asserted"); South v Saab Cars USA, Inc, 28 F3d 9, 11 (2d Cir 1994) (explaining that "[t]he doctrine of equitable tolling has ... been applied where the court has led the plaintiff to believe that she had done all that was required of her").

1718 CFR $\S 292.3($ a).

172 Id. 
Finally, even assuming some level of collusion occurs, the potential harm to society does not outweigh the harm to non-colluding aliens whose lives would be destroyed without a hearing to contest their deportation. Unlike in many cases where time is of the essence, ${ }^{173}$ a deportation delay implicates no significant claim on the country's revenues, land interests, or adverse claims; indeed, it is hard to imagine how tolling a deportation order might substantially prejudice societal interests.

Conversely, to restrict tolling for fear of potential collusion would cause devastating damage to a "good faith" alien whose life is destroyed without so much as a hearing. Equitable tolling does not confer any advantage, unjust reward, or windfall; instead, it simply allows an alien to file an appeal to contest a decision that may well be the most important event of his life. It seems arbitrary and needless for an alien to forfeit his chance to examine witnesses, tell his story, and be more than a name on a judge's docket, all because he followed his attorney's erroneous advice. The in absentia deportation proceeding is one of the harshest penalties our society imposes; we need not exacerbate it by denying trusting aliens the basic right to appeal the decision.

\section{CONCLUSION}

The INA's 180-day filing deadline for contesting in absentia deportation orders is best viewed as an equitably tollable statute of limitations, rather than a limit on courts' jurisdiction. Irwin establishes a presumption that courts should read equitable tolling into all federal statutes absent contrary congressional intent, and nothing in the INA's text, legislative history, or purpose suggests that Congress intended to curb courts' equitable powers in the deportation context. Where an alien or his attorney receives notice of a deportation hearing, a court should equitably toll the filing deadline only when an attorney's misfeasance proximately causes an alien to miss his hearing and the subsequent appeals deadline. 